\title{
The willingness to pay for access to piped water: a hedonic analysis of house prices in Southwest Sri Lanka
}

\author{
Caroline van den Berg • Céline Nauges
}

Received: 3 January 2011 / Accepted: 2 February 2012 / Published online: 23 February 2012

(C) The Author(s) 2012. This article is published with open access at Springerlink.com

\begin{abstract}
We apply a hedonic house price analysis to value connection to the piped water network in Southwest Sri Lanka based on a household survey that was conducted in 2003-04. We find that the willingness-to-pay for a piped water connection is on average about 5 percent of monthly household expenditure, which is at the lower end of the range from estimates obtained in case studies in other developing countries. In addition, the willingness-to-pay for piped water decreases as a proportion of income when income goes up. An important policy conclusion is that connection to the piped water system should be considered in relation to the availability and quality of alternative water sources. If alternative sources with good water quality are available, the need for a piped water connection is less urgent.
\end{abstract}

Keywords Household behavior · Piped water services · Hedonic pricing method · Development planning and policy $\cdot$ Sri Lanka

JEL Classification D12 $\cdot \mathrm{H} 4 \cdot \mathrm{O} 2 \cdot \mathrm{Q} 25 \cdot \mathrm{Q} 52$

\section{Introduction}

The World Health Organization and UNICEF's Joint Monitoring Programme (2010) estimated that in 2008 about 884 million people in urban areas in developing countries lacked access to safe water. Yet, these numbers do not capture the often low

The opinions reflected in this paper are the opinions of the authors and not opinions of the World Bank, the University of Queensland.

C. van den Berg $(\varangle)$

Middle East and North Africa's Sustainable Development Department, Word Bank,

1818 H Street NW, Washington DC, USA

e-mail: cvandenberg@worldbank.org

C. Nauges

School of Economics, University of Queensland, Brisbane Qld, 4072, Australia 
quality of the services that are provided. The need for reform of water and sanitation service delivery is therefore urgent, especially in urban areas. Many countries are embarking on organizational reforms that are needed to improve water provision, which include changes in the way utilities are managed, higher charges for water and sewerage services, ${ }^{1}$ and regulation of the sector. Insight into households' preferences for access to safe, accessible water is needed for the development of the reforms under consideration.

Households' decisions to connect to a piped (safe) water network are based on the comparison of associated costs and expected benefits. The connection costs are usually not too difficult to quantify. Yet, estimating benefits is often complicated, as it requires insight into the households' expected changes in welfare from getting a private connection to the network. ${ }^{2}$

Households without a connection to the piped network face several costs. First, they face hauling costs to collect water from non-piped sources (private or public wells, public taps, water vended from trucks, etc.). Second, in some cases they have to pay high prices per unit of non-piped water purchased. Finally, non-piped water may be of lower quality than water provided through the piped water system. Hence, connecting a household to the piped water network is likely to make access to safe water easier, unit prices lower, and the incidence of water-related diseases smaller.

The value of a connection to the piped network can be estimated using either stated preference or revealed preference methods. A typical stated preference approach is to ask a sample of unconnected households about their maximum willingness to pay for a water connection. This approach has been widely used, for example, by Whittington et al. (2002) for Nepal and Pattanayak et al. (2004) for Sri Lanka.

The most common revealed preference approach is the "hedonic property valuation method". This approach infers the value of water connections from differences in property values according to connection status. It has been used in developing countries, among others, by North and Griffin (1993) for the Philippines. They find a willingness to pay of 2.4 percent of monthly household income (which corresponds to 47 percent of monthly rent) or less, with the share falling as income rises. Comparable estimates have been found by Whittington et al. (1990) for rural Kenya and Yusuf and Koundouri (2005) for Indonesia. De Oca et al. (2003) find that households are willing to pay 5.8 percent of their monthly household income for well-maintained services and up to 8.3 percent for improved services in Mexico City. Harapap and Hartono (2007) estimate that the availability of piped or pumped water in Indonesia increases house rental prices in urban areas by 9.1 percent. Somewhat lower results have been obtained by Suparman et al. (2009) who estimate the value of piped water at approximately 8 percent of mean household monthly income in rural and urban areas in Indonesia. Nauges et al. (2009) find that tap water connection adds 10-52 percent to the sales value of a house in El Salvador, depending on the non-tap source. For poor

\footnotetext{
${ }^{1}$ Piped water supply is almost universally subsidized although the levels of subsidies tend to decrease when countries get richer and the cost of piped water as a percentage of household income decreases.

${ }^{2}$ Piped water is, technically speaking, a private good. Yet, because of its public health benefits, there is widespread consensus that piped water should be provided on a large scale. As such piped water has a public good character. Hence, the price that consumers pay for piped water supply tends to be only loosely, if at all, related to its scarcity and value.
} 
neighborhoods in Guatemala they obtain a lower range of 14-19 percent. Anselin et al. (2008) find a hedonic price of INR 170 in Bangalore (2001) and INR 119 in Bhopal (2003), but without reference to household incomes.

The present paper reports hedonic price analysis results based on a household survey in Southwest Sri Lanka in 2003-04. This survey was undertaken to support the Government of Sri Lanka in its decision to engage private operators in managing and expanding water and sewerage services in two services areas (Greater Negombo and the Kalutara-Galle coastal strip). The basic objective of the survey was to get a better understanding of the demand for piped water services, and hence consumer preferences, which would be used to shape the envisaged private sector participation. Particularly, estimates of the willingness to pay for connection to the piped network would be used to calculate connection fees and monthly service charges, which would not discourage households to connect; for further details see Van den Berg et al. (2006). The results obtained in this paper complement Pattanayak et al. (2006) who estimate the willingness to pay for piped water by means of contingent valuation for the same sample of households.

The organization of this paper is as follows. In Sect. 2, we discuss the hedonic price method and in Sect. 3 the sampling design and the model specification. In Sect. 4 we present the estimation results and in Sect. 5 the main conclusions.

\section{The hedonic house price method}

Hedonic house price equations relate an estimate of a property's market value to various characteristics of the property, i.e. structural characteristics (square feet of living space, dwelling age, number of stories, number of rooms, etc.) and neighborhood amenities (distance to school, work, access to public services, environmental amenities, etc.). The hedonic pricing method is used to measure the willingness to pay for an amenity, in this case access to a piped water connection. For that purpose, one ideally would like to compare households with identical preferences in situations that differ only in whether the household has access to a piped water connection or not. Preferences are, however, often very heterogeneous, Rosen shows that this complication can be overcome by concentrating on the marginal willingness to pay for the amenity in question. Rosen also assumes perfect competition and perfect observability of characteristics. These assumptions are not necessarily applicable in the housing market where perfect competition is often affected by many different types of regulation. In addition, not all housing characteristics are always observable. Bajari and Benkard (2005) show that Rosen's approach can be generalized to allow for imperfect competition and unobserved characteristics, which is likely to increase the value of the hedonic pricing method. ${ }^{3}$

Following Rosen (1974), the general specification of our hedonic house price equation is:

$$
V=f(S, N, W)
$$

\footnotetext{
${ }^{3}$ The approach proposed by Bajari and Benkard (2005) and its use of non-parametric methods (in the first-stage estimation) is outside the scope of this study.
} 
where $V$ is the estimated market value of the property (sales price), $S$ denotes a set of structural characteristics, $N$ a set of neighborhood amenities, and $W$ represents the types of water services available (piped network, other non-piped water sources). The first order derivative of the hedonic price function with respect to one such characteristic yields an indirect estimate of the willingness-to-pay for this particular characteristic.

Theory has provided little guidance regarding the functional form of the relationship between property value and the set of explanatory variables. Various specifications have been used including linear, semi-ln and $\ln -\ln$, as well as search-based specifications using Box-Cox transformations (Box and Cox 1964). More recently, semi-parametric or fully non-parametric specifications have been applied (see Ekeland et al. 2004). Furthermore, structural equation models (SEM) have been introduced into the hedonic price literature by Suparman et al. (2009). Applications of the hedonic approach to value house characteristics can be found in Freeman (1993), Daniere (1994), Anselin et al. (2008), and Suparman et al. (2009).

Hedonic price models are usually based on actual sales or rents. In developing countries, however, actual sales may be affected by high transaction costs, while data on transactions may be incomplete. Moreover, housing markets are often not perfectly competitive, sales transactions are often infrequent, and regulatory control can result in artificially low rent values (Nauges and van den Berg 2009). ${ }^{4}$ Therefore, owner stated values, obtained from household surveys, are often used instead. The literature shows that the discrepancy between actual and estimated value is relatively modest - from -2 percent (Kain and Quigley 1972) up to 6 percent (Goodman and Ittner 1992).

Access to piped water services may result in reciprocal positive spillover among houses. For instance, the value of a connected house may go up because it can offer piped water service to its unconnected neighbors. In a similar vein, the values of unconnected houses in the vicinity of a connected house may go up. There is no information in the dataset to account for this feature, which means that the value of both connected and unconnected houses may be undervalued. However, connected and non-connected houses tend to be grouped in clusters. Therefore, we expect this feature to play a minor role.

\section{Sample design and model specification}

\subsection{The sample}

The three survey districts were Greater Negombo, Kalutara and Galle from which we selected a sample of households by way of a two-stage stratified-random procedure. The sample size of 1,813 households was determined on the basis of precision in estimates. In Stage 1, we selected within each district geographical strata (so-called

\footnotetext{
${ }^{4}$ Housing markets in developed countries are also affected by external influences, such as for instance tax concessions (e.g., mortgage interest deductions).
} 
Grahma Niladhari (GN) divisions) ensuring sufficient geographical coverage and spatial variation. For each GN we determined the number of interviewees as a fixed proportion of its population. In Stage 2 we randomly selected the households in each GN stratum. For details we refer to Pattanayak et al. (2004). The random selection of these households ensures that our sample is representative and allows us to generalize its findings.

Most households in the area under investigation own their houses-with only 6 percent renting their premises. The profile of the latter in terms of water sources and income is not very different from the average homeowner, except with regard to the use of private wells and vendors-with renters less likely to use private wells, and more likely to rely on vendors. There are statistically significant differences in imputed rent between renters and homeowners - with renters indicating substantially lower rents than homeowners, which may be due to artificially low rents as a consequence of rent control, which was prevalent in Sri Lanka until the 1980s. ${ }^{5}$ We therefore excluded renters (114) and those homeowners who did not provide housing value data (147). The ultimate sample size is thus 1,552 .

\subsection{Model specification}

The dependent variable is the answer by the interviewee, i.e. the head of household, to the question of what the market value of her or his house would be, if it were sold at the day of the interview. Explanatory variables are:

Structural characteristics including the number of rooms, the number of sealed toilets, the materials used for walls and roof, and possession of an overhead storage tank. The last three characteristics are dummy variables, i.e. 1 for red bricks or cement; 1 for roof is tiles; and 1 for possession of a storage tank. Presence of toilets is a categorical variable: 0 for no toilets, 1 for one toilet and 2 for two or more toilets. We expect all structural characteristics coded 1 or higher to have positive impacts on property value.

Neighborhood characteristics. We use average monthly per capita household income and average number of years of education of the head of households in the municipality ${ }^{6}$ in which the property is located as proxies for the standard of living. We expect positive signs: the higher the standard of living, the higher the house value. The proportion of Samurdhi (the government's welfare program) recipients is expected to be negatively correlated with house values. Other neighborhood amenities included in the analysis are the distances from home to schools (primary and secondary school, college), to a dispensary, to a hospital and to roads. However, many of these amenities do not differ significantly between connected and non-connected households. Hence, we focus on the distance to the nearest paved road as the main

\footnotetext{
${ }^{5}$ Rent control is guided by the Rent Act of 1972 and the various amendments, including that of 2002. Residential premises occupied by the owner or constructed after January 1, 1980 are not subject to the Rent Act. As only 6 percent of the respondents was renting, and only a proportion of that 6 percent lives in houses that were constructed before 1980, it is likely that the effects of rent control are very limited.

${ }^{6}$ The area is divided into three districts. These three districts are made up of 17 municipalities, which are used to calculate the average income in the municipality, the average presence of Samurdhi recipients, and the average level of education of the head of household.
} 
amenity. This characteristic is expected to have a negative sign: the farther away from the road, the lower the house appraisal value. We also include district dummies.

Access to water source. We consider access to and use of water from the piped network (i.e., a private connection) versus access to and use of alternative sources (i.e. private wells, public tap, public well, surface water and vendors). In each case we use a dummy variable that equals 1 if the household is collecting water from this source and 0 otherwise. Note that most households either use water from the piped water system or from private wells. Many households also use other non-piped water sources, but often as supplement, not as a main source. Households were not only questioned about the water sources they had access to, but also the walking time to the source. However, in most cases, households did not know how much time it took to go to the sources that they only incidentally used. Therefore, this variable was not considered as an explanatory variable.

Obviously, there are many more variables that could be included in the hedonic pricing model. However, availability of data is a major constraint in this part of Sri Lanka and hence it was not possible to include more data than the ones described above.

\subsection{Adjusted model specification}

In a second model, we will augment the above model with a set of household socioeconomic characteristics that proxies knowledge and perceptions. Recent literature shows that knowledge and perceptions have an important effect on economic behavior. This is especially important in decisions on housing values where decisions (apart from a rational part) also has a more emotional character. We assume that the impact of knowledge and perceptions will be captured by the following three variables: per capita household income, being a Samurdhi (welfare) recipient, and average years of education of the head of the household. We expect property valuation to vary by these variables, since they are proxies for the impact of knowledge and perceptions. This expectation is supported by Keskin (2008) and Suparman et al. (2009) who find significant relationships between household socioeconomic status and imputed rent. We expect per capita household income to impact house appraisal value positively, because households with higher incomes are more likely to appreciate house and neighborhood amenities than low income households, e.g. because of experience or access to information. Education of the head of household, measured in number of years of formal schooling, is included because we expect individuals with more formal schooling to be more knowledgeable and hence have a higher ability to accurately evaluate structural and neighborhood characteristics and the benefits of a piped water connection. The sign of the impact of education is uncertain. The probability of a household depending on Samurdhi payments is likely to have a negative impact on house prices. We expect this second model to result in lower levels of willingness to pay for piped water services as the availability of safe water sources (other than piped water services) in this part of Sri Lanka is relatively easy, and hence may adversely affect people's willingness to pay for piped water services. 
Table 1 Descriptive statistics for connected and unconnected households

\begin{tabular}{|c|c|c|c|}
\hline & $\begin{array}{l}\text { Non- } \\
\text { connected } \\
\text { households } \\
\text { (mean) }\end{array}$ & $\begin{array}{l}\text { Connected } \\
\text { households } \\
\text { (mean) }\end{array}$ & $\begin{array}{l}\text { Mean com- } \\
\text { parison test } \\
(p \text {-value })\end{array}$ \\
\hline Average house value (in LKR) (ln) & 13.01 & 13.31 & 0.000 \\
\hline \multicolumn{4}{|l|}{ Structural characteristics } \\
\hline Average number of rooms & 1.23 & 1.28 & 0.033 \\
\hline Average number of sealed toilets & 1.17 & 1.25 & 0.001 \\
\hline $\begin{array}{l}\text { Red bricks/cement used for walls } \\
\text { (proportion) }\end{array}$ & 0.94 & 0.98 & 0.000 \\
\hline Tiles used for roof (proportion) & 0.82 & 0.74 & 0.000 \\
\hline Storage tank (proportion) & 0.46 & 0.41 & 0.027 \\
\hline \multicolumn{4}{|l|}{ Neighborhood characteristics } \\
\hline $\begin{array}{l}\text { Average household income in } \\
\text { municipality (in LKR) (ln) }\end{array}$ & 9.7 & 9.78 & 0.000 \\
\hline $\begin{array}{l}\text { Samurdhi recipients in municipality } \\
\text { (proportion) }\end{array}$ & 0.18 & 0.20 & 0.000 \\
\hline $\begin{array}{l}\text { Household located in Negombo } \\
\text { (proportion) }\end{array}$ & 0.74 & 0.26 & 0.000 \\
\hline $\begin{array}{l}\text { Household located in Kalutara } \\
\text { (proportion) }\end{array}$ & 0.72 & 0.28 & 0.003 \\
\hline Household located in Galle (proportion) & 0.55 & 0.45 & 0.000 \\
\hline Average distance to pre-school $(\mathrm{km})(\mathrm{ln})$ & 0.57 & 0.08 & 0.019 \\
\hline Average distance to hospital (km) (ln) & -0.04 & -0.60 & 0.000 \\
\hline Average distance to road (km) (ln) & 1.34 & 1.02 & 0.000 \\
\hline Average distance to beach $(\mathrm{km})(\mathrm{ln})$ & 1.39 & 0.77 & 0.000 \\
\hline \multicolumn{4}{|l|}{ Socio-economic characteristics } \\
\hline $\begin{array}{l}\text { Average household monthly income (in } \\
\text { LKR) (ln) }\end{array}$ & 9.42 & 9.58 & 0.000 \\
\hline $\begin{array}{l}\text { Average household per capita monthly } \\
\text { income (in LKR) (ln) }\end{array}$ & 7.93 & 8.04 & 0.004 \\
\hline Proportion of Samurdhi recipients & 0.21 & 0.15 & 0.004 \\
\hline $\begin{array}{l}\text { Average number of years of education } \\
\text { by head of household }(\ln )\end{array}$ & 1.93 & 2.12 & 0.002 \\
\hline \multicolumn{4}{|l|}{ Water sources } \\
\hline Piped water (proportion) & 0.00 & 1.00 & 0.000 \\
\hline $\begin{array}{l}\text { Other water sources as main source } \\
\text { (proportion) }\end{array}$ & 1.00 & 0.00 & 0.000 \\
\hline
\end{tabular}

\section{Empirical results}

\subsection{Descriptive statistics}

Descriptive statistics by connected and unconnected households are presented in Table 1. Simple tests of means between both types of households are included (last 
column). We only discuss significant differences. Note that 39 percent of the households are connected.

Average monthly income (including total monthly income of all wage earners in the household, plus any other income, plus any money remitted to the household by a family member working outside the country) for connected households is about 30 percent higher than the average of unconnected households. The mean comparison tests also suggest that connected households tend to live in houses with more rooms and sealed toilets than unconnected households. Unconnected households are more likely to have tiles as roof material than connected households, while the opposite holds for red bricks/cement for walls. Furthermore, a larger proportion of unconnected households have a storage tank.

As far as neighborhood characteristics are concerned, there are significant differences in terms of distance to pre-school, hospital, beach, and distance to a paved road between connected and unconnected households. Particularly, unconnected households tend to be located further away from these amenities. Average municipality income is higher for connected than for unconnected households. Non-connected households are concentrated in the Negombo district and connected households in the Galle district. The Kalutara district is mixed.

As far as socio-economic characteristics are concerned connected households have higher total and per capita income, and their household heads have more years of education than unconnected households. In addition, 21 percent of the non-connected households are Samurdhi recipients, but only 15 percent of the connected households.

Unconnected households mainly collect water from four sources: public taps, public wells, neighbors (private tap or private well), and private wells. Nauges and van den Berg (2009) show that the lowest time cost (to collect water) is borne by households having private wells, followed by households relying on water provided by neighbors. It takes on average about 5 minutes to go to community sources (public tap or well), and waiting time can be up to 24 minutes. Water from non-piped sources, except vendors, is free. However households who collect water from wells need equipment, which can be a bucket and a rope (for the vast majority of households), a hand pump, or more costly and technically more advanced equipment, such as an electric pump. Overall, unconnected households are satisfied with the quality (i.e., taste, color, smell, and safety) and service of non-piped water. More precisely, 90 percent of households collecting water from public taps, neighbors, and private wells, believe that water from these sources is safe. This percentage is slightly lower for households relying on public wells: 60 percent of these households think that there is "no risk" or "little risk" in drinking water from the public well.

Connected households were also questioned about their judgment of the piped water service. The majority believes that water supplied through the network is safe. However, there were frequent complaints about piped water being available for less than 24 hours a day. Indeed, in the rainy (dry) season, only 31 percent ( 22 percent) of connected households have 24 hour service; and 36 percent ( 42 percent) have access for 12 hours or less a day.

To sum up, satisfaction with access to and quality of water is very high in this part of Sri Lanka, whether a household has access to a piped water connection, a private well, or depends on a neighbor for water supply. This means that the willingness 
to pay for connection to the piped system is likely to be rather low, since obtaining access to a piped water connection is not seen as a big improvement in terms of water safety and quality. We therefore expect the willingness to pay for a piped water connection in our study area to be at the lower end of the range of studies such as Suparman et al. (2009) and Nauges et al. (2009).

\subsection{The hedonic price model}

Functional form search led to the selection of a log-linear model with the dependent variable and the independent variables (except the dummies) in logarithms. In order to avoid biases due to very small or very large values, we cut the distribution of house values below the 1 percentile and above the 99 percentile, ${ }^{7}$ which reduced the sample to 1,552 observations. In this reduced sample, 607 households (39 percent of the sample) have a connection to the piped network, 829 households rely on private well water as their main source, 89 households used water provided by neighbors and 27 households depended on community sources including public wells, public taps, and surface water. A significant number of households use more than one source of water; yet, these supplementary sources have not been considered separately.

The Ordinary Least Squares (OLS) estimates results are presented in Table 2. Before going into detail, we observe that some variables (material used for floor, distance to certain types of amenities) turned out to be highly insignificant. Therefore, they were removed from the model, which reduced multi-collinearity. The overall fit of the final model, as measured by the adjusted R-square, is 0.41 .

Most of the remaining variables are significant at conventional levels and have the expected signs. Structural characteristics are highly significant. Particularly, the number of rooms, the presence of toilets, a roof made of tiles, walls made of bricks or cement, and access to an overhead storage tank have positive effects on house appraisal value, as hypothesized.

The neighborhood's average household income has the expected positive sign: the higher the average household income, the higher the house appraisal value. The proportion of government welfare (Samurdhi) recipients in the municipalities on the other hand has a negative impact. The average number of years of education of the head of household had the expected positive sign, but was insignificant. Furthermore, distance to the road indicates that the further a house is located away from the road, the lower its appraisal value. The regional dummies are also significant. Properties in Kalutara and Galle tend to have lower house values than those in Negombo, which is closer to the capital and tends to have more economic activity than the other regions. Connection to the piped water network has a significant, positive coefficient.

\subsection{The adjusted hedonic price model}

The OLS estimates results for the adjusted hedonic pricing model are presented in Table 3. The overall fit of the reduced model, as measured by the adjusted R-square, is 0.45 , compared to 0.41 for the conventional model.

\footnotetext{
${ }^{7}$ The coefficient measuring the impact of a connection was not affected by deletion of the tails. The overall fit of the model improved, however.
} 
Table 2 OLS estimation results of the conventional hedonic house price model

\begin{tabular}{|c|c|c|c|}
\hline Dependent variable (ln of house appraisal value) & Coefficient & Std. err. & $p$ value \\
\hline Constant & $7.575^{* * *}$ & 1.013 & 0.000 \\
\hline \multicolumn{4}{|l|}{ Structural characteristics } \\
\hline Number of rooms $(\ln )$ & $0.640^{* * *}$ & 0.052 & 0.000 \\
\hline Number of toilets ${ }^{\mathrm{a}}(0 / 1 / 2)$ & $0.467^{* * *}$ & 0.052 & 0.000 \\
\hline Wall is made of red bricks or cement (otherwise reference ) & $0.929 * * *$ & 0.113 & 0.000 \\
\hline Roof is made of tiles (otherwise reference case) & $0.143^{* *}$ & 0.054 & 0.008 \\
\hline Overhead storage tank (not available reference case) & $0.323^{* * *}$ & 0.048 & 0.000 \\
\hline \multicolumn{4}{|l|}{ Neighborhood characteristics } \\
\hline Mean household income by municipality (ln) & $0.355^{* * *}$ & 0.112 & 0.002 \\
\hline Percentage of Samurdhi recipients by municipality & $-1.856^{* * *}$ & 0.414 & 0.000 \\
\hline Distance to road in $\mathrm{km}(\mathrm{ln})$ & $-0.071^{* * *}$ & 0.022 & 0.001 \\
\hline \multicolumn{4}{|l|}{ Negombo district (reference case) } \\
\hline Kalutara district $(0 / 1)$ & $-0.208^{* * *}$ & 0.056 & 0.000 \\
\hline Galle district $(0 / 1)$ & $-0.110^{*}$ & 0.051 & 0.032 \\
\hline \multicolumn{4}{|l|}{ Water source } \\
\hline \multicolumn{4}{|l|}{ Household has access to non-piped sources only (reference) } \\
\hline Household has access to private piped water connection $(0 / 1)$ & $0.195^{* * *}$ & 0.048 & 0.000 \\
\hline Number of observations & $1,523^{\mathrm{b}}$ & & \\
\hline Adjusted R-squared & 0.41 & & \\
\hline
\end{tabular}

$* * *, * *, *$ Indicate significance at the 1,5 , and $10 \%$ level, respectively

a Presence of toilet: $0=$ no toilet, $1=$ one toilet only, $2=$ two or more toilets

${ }^{b}$ The sample on which the model is estimated is smaller than the sample of 1,552 households discussed in Sect. 4 , because of non-response in some of the explaining variables, which reduces the total number of included observations to 1,523

Most of the remaining variables are significant at conventional levels and have the expected signs. Structural characteristics are highly significant, and so are the neighborhoods characteristics. Introducing socio-economic characteristics as a proxy for impact of perceptions and knowledge shows that the connection to the piped water network has a significant, positive coefficient, but that it is lower than in the traditional hedonic pricing model (Table 2). ${ }^{8}$ This tendency of hedonic pricing models to provide an upper bound of willingness to pay has been noted by different authors (Vaughan and Ardila 1993; Carson et al. 1996).

In the next subsection we use this piece of information to derive the marginal willingness to pay for a private piped water connection.

\footnotetext{
${ }^{8}$ Note however that the estimated coefficients of a piped water connection in the conventional and adjusted models are not statistically different, in the sense that the corresponding $95 \%$ confidence intervals overlap.
} 
Table 3 OLS estimation results of the adjusted hedonic house price model

\begin{tabular}{|c|c|c|c|}
\hline Dependent variable (ln of house appraisal value) & Coefficient & Std. err. & $p$ value \\
\hline Constant & $5.818^{* * *}$ & 1.096 & 0.000 \\
\hline \multicolumn{4}{|l|}{ Structural characteristics } \\
\hline Number of rooms $(\ln )$ & $0.556^{* * *}$ & 0.052 & 0.000 \\
\hline Number of toilets ${ }^{\mathrm{a}}(0 / 1 / 2)$ & $0.334^{* * *}$ & 0.052 & 0.000 \\
\hline Wall is made of red bricks or cement (otherwise reference ) & $0.847^{* * *}$ & 0.111 & 0.000 \\
\hline Roof is made of tiles (otherwise reference case) & $0.138^{* *}$ & 0.053 & 0.009 \\
\hline Overhead storage tank (not available reference case) & $0.219^{* * *}$ & 0.048 & 0.000 \\
\hline \multicolumn{4}{|l|}{ Household socio-economic characteristics } \\
\hline Monthly household income (ln) & $0.267^{* * *}$ & 0.033 & 0.000 \\
\hline Household is Samurdhi recipient & $-0.271^{* * *}$ & 0.060 & 0.000 \\
\hline Education of head of household in number of years $(\ln )$ & $0.031^{*}$ & 0.018 & 0.086 \\
\hline \multicolumn{4}{|l|}{ Neighborhood characteristics } \\
\hline Mean household income by municipality (ln) & $0.310^{* * *}$ & 0.109 & 0.005 \\
\hline Percentage of Samurdhi recipient by municipality & $-1.553^{* * *}$ & 0.406 & 0.000 \\
\hline Distance to road in $\mathrm{km}(\mathrm{ln})$ & $-0.071^{* * *}$ & 0.021 & 0.000 \\
\hline \multicolumn{4}{|l|}{ Negombo district (reference case) } \\
\hline Kalutara district $(0 / 1)$ & $-0.175^{* * *}$ & 0.055 & 0.001 \\
\hline Galle district $(0 / 1)$ & $-0.094 *$ & 0.050 & 0.062 \\
\hline \multicolumn{4}{|l|}{ Water source } \\
\hline \multicolumn{4}{|l|}{ Household has access to non-piped sources only (reference) } \\
\hline Household has access to private piped water connection $(0 / 1)$ & $0.152^{* * *}$ & 0.047 & 0.001 \\
\hline Number of observations & $1,491^{\mathrm{b}}$ & & \\
\hline Adjusted R-squared & 0.45 & & \\
\hline
\end{tabular}

$* * *, * *, *$ Indicate significance at the 1,5 , and $10 \%$ level, respectively

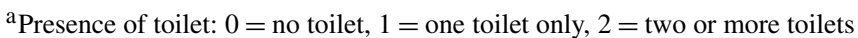

${ }^{b}$ The sample on which the model is estimated is smaller than the sample of 1,552 households discussed in Sect. 4 , because of non-response in some of the explaining variables, which reduces the total number of included observations to 1,491

\subsection{The marginal willingness-to-pay for a private connection}

We now turn to the derivation of the marginal willingness-to-pay for connection to the public water system. Coefficient $\hat{\beta}$ in Tables 2 and 3 denote the difference in $\ln$ value between connected and unconnected houses and the absolute increase in house value from the connection to the piped network is $V^{\mathrm{NC}}\left(e^{\hat{\beta}}-1\right)$ or in percentages:

$$
\frac{V^{\mathrm{NC}}\left(e^{\hat{\beta}}-1\right) \times 100}{V^{\mathrm{NC}}}=\left(e^{\hat{\beta}}-1\right) \times 100 .
$$


Table 4 Predicted increase in house value after connection according to the basic hedonic pricing model (overall, monthly equivalent, \% of monthly household income)

\begin{tabular}{|c|c|c|c|c|c|}
\hline \multicolumn{2}{|c|}{ Predicted increase in house value (LKR) } & \multicolumn{2}{|c|}{$\begin{array}{l}\text { Monthly equivalent of } \\
\text { increase in house value } \\
\text { (LKR) }\end{array}$} & \multicolumn{2}{|c|}{$\begin{array}{l}\text { As \% of monthly } \\
\text { household income } \\
\text { (non-connected) }\end{array}$} \\
\hline $\begin{array}{l}\text { Mean } \\
{[95 \% \text { confidence }} \\
\text { interval }]\end{array}$ & $\begin{array}{l}\text { Median } \\
{[95 \% \text { confidence }} \\
\text { interval] }\end{array}$ & $\begin{array}{l}\text { Mean } \\
{[95 \%} \\
\text { confidence } \\
\text { interval }]\end{array}$ & $\begin{array}{l}\text { Median } \\
{[95 \%} \\
\text { confidence } \\
\text { interval] }\end{array}$ & $\begin{array}{l}\text { Mean } \\
{[95 \%} \\
\text { confidence } \\
\text { interval] }\end{array}$ & $\begin{array}{l}\text { Median } \\
{[95 \%} \\
\text { confidence } \\
\text { interval] }\end{array}$ \\
\hline $\begin{array}{l}97,149 \\
{[47,839 ; 151,437]}\end{array}$ & $\begin{array}{l}100,430 \\
{[49,454 ; 156,550]}\end{array}$ & $\begin{array}{l}810 \\
{[399 ; 1,262]}\end{array}$ & $\begin{array}{l}837 \\
{[412 ; 1,305]}\end{array}$ & $\begin{array}{l}6.6 \% \\
{[3.2 \% ; 10.2 \%]}\end{array}$ & $\begin{array}{l}7.0 \% \\
{[3.4 \% ; 10.9 \%]}\end{array}$ \\
\hline
\end{tabular}

In the conventional hedonic pricing model, $\hat{\beta}=0.195$ ( 0.152 in the adjusted model), which translates into a relative increase in house value (after connection) of about 22 (in the adjusted model reduced to 16 ) percent. However, $\hat{\beta}$ is estimated with error. The $95 \%$ confidence interval for $\hat{\beta}$ is [0.061 and 0.247 ], which corresponds to a $95 \%$ interval of [6\% and 25\%] in percentages when the basic hedonic pricing model is used.

\subsection{The average monthly income equivalent}

We define the average monthly equivalent of the increase in house value due to connection as $1 / 12$ of the discounted annualized increase. We use a discount rate of 10 percent, which is the rate charged by a self-help group or microfinance institution. In Table 4 we report in the first column the predicted increase in house value after connection to the piped network (based on the estimated parameter $(\hat{\beta}=0.195)$ of the connection dummy variable), and the monthly equivalent, in absolute terms and as a percentage of monthly household income. We find that non-piped households on average would be willing to pay each month about LKR 810 (median LKR 837), which is about 6.6 percent of their monthly household income, to get a connection to the piped network. ${ }^{9}$ When using the adjusted model that takes a better account of the perceptions and knowledge, the results are significantly lower and non-piped households are on average willing to pay only LKR 614 (median LKR 701) which is about 5 percent of their monthly household income as shown in Table 5. These numbers are in the range of North and Griffin (1993) for the Philippines, De Oca et al. (2003) for Mexico, Nauges et al. (2009) for Central America, and Suparman et al. (2009) for Indonesia.

In Table 6 we show the monthly equivalents for different income groups. The first quartile is the 25 percent of households with the lowest per capita income, and so on. Table 6 shows that the expected willingness-to-pay for access to a private connection decreases as a proportion of income when income goes up, although there is a kink whereby the expected willingness-to-pay decreases from the first to the second quartile, but it increases in the third quartile, after which it decreases in the fourth

\footnotetext{
${ }^{9}$ The total increase in house value due to the water connection is on average LKR 97,149, which translates into a monthly value of LKR97, $194 \times 1 / 12 \times 10$ percent $=$ LKR 810; and an annual value of LKR 9,715.
} 
Table 5 Predicted increase in house value after connection using the adjusted hedonic pricing model (overall, monthly equivalent, \% of monthly household income)

\begin{tabular}{|c|c|c|c|c|c|}
\hline \multicolumn{2}{|c|}{ Predicted increase in house value (LKR) } & \multicolumn{2}{|c|}{$\begin{array}{l}\text { Monthly equivalent of } \\
\text { increase in house value } \\
\text { (LKR) }\end{array}$} & \multicolumn{2}{|c|}{$\begin{array}{l}\text { As \% of monthly } \\
\text { household income } \\
\text { (non-connected) }\end{array}$} \\
\hline $\begin{array}{l}\text { Mean } \\
{[95 \% \text { confidence }} \\
\text { interval }]\end{array}$ & $\begin{array}{l}\text { Median } \\
\text { [95\% confidence } \\
\text { interval] }\end{array}$ & $\begin{array}{l}\text { Mean } \\
{[95 \%} \\
\text { confidence } \\
\text { interval] }\end{array}$ & $\begin{array}{l}\text { Median } \\
{[95 \%} \\
\text { confidence } \\
\text { interval] }\end{array}$ & $\begin{array}{l}\text { Mean } \\
{[95 \%} \\
\text { confidence } \\
\text { interval] }\end{array}$ & $\begin{array}{l}\text { Median } \\
{[95 \%} \\
\text { confidence } \\
\text { interval] }\end{array}$ \\
\hline $\begin{array}{l}73,732 \\
{[27,564 ; 124,382]}\end{array}$ & $\begin{array}{l}84,089 \\
{[31,435 ; 141,853]}\end{array}$ & $\begin{array}{l}614 \\
{[230 ; 1,037]}\end{array}$ & $\begin{array}{l}701 \\
{[262 ; 1,182]}\end{array}$ & $\begin{array}{l}5.0 \% \\
{[1.9 \% ; 8.4 \%]}\end{array}$ & $\begin{array}{l}5.9 \% \\
{[2.2 \% ; 9.9 \%]}\end{array}$ \\
\hline
\end{tabular}

Table 6 Increase in house value for unconnected households as share of monthly household income, by income quartile—basic and adjusted hedonic pricing model compared

\begin{tabular}{llrlrr}
\hline & \multicolumn{2}{l}{ Basic hedonic pricing model } & & \multicolumn{2}{c}{ Adjusted hedonic pricing model } \\
\cline { 2 - 3 } & Mean & Median & & Mean & Median \\
\hline First income quartile & $8.2 \%$ & $11.2 \%$ & $5.6 \%$ & $8.0 \%$ \\
Second income quartile & $6.4 \%$ & $6.7 \%$ & $4.8 \%$ & $5.7 \%$ \\
Third income quartile & $6.3 \%$ & $7.7 \%$ & $5.2 \%$ & $6.2 \%$ \\
Fourth income quartile & $4.3 \%$ & $4.6 \%$ & $4.2 \%$ & $4.4 \%$ \\
\hline
\end{tabular}

Note: the definition of the quartiles was based on per capita income

quartile. It shows that compared to the basic hedonic pricing model, the willingness to pay for piped water is significantly lower for the poorer quartiles when using the adjusted hedonic pricing model. The fact that average living conditions can vary significantly within neighborhoods whereas income differentials can be high, means that when corrected for socio-economic characteristics, basic hedonic pricing models that do not take this factor in account may estimate higher willingness to pay for piped water especially for poorer households.

Access to piped water is conditional on location. If a household is not located within a certain distance from the existing network, the cost of a piped water connection tends to become prohibitively high. In part of the survey area, there is no immediate access to the piped network (measured as a distance of one kilometer or more from the piped network). The willingness-to-pay for piped water in areas outside the network reach tends to be lower than for households within the network, as can be seen in Table 7. This effect may be related to the fact that these households expect that obtaining access to a piped water connection is unrealistic, at least in the short run and hence discount the value of a piped water connection. According to the basic hedonic pricing model, households out of network are willing to pay on average 6.2 percent of their monthly household income, compared to 6.7 percent when the households are located in the network. When the adjusted hedonic pricing model is used, households out of network reach are willing to pay on average 4.6 percent of their monthly household income compared to 5.1 percent for those within reach of 
Table 7 Increase in house value for unconnected households as a share of monthly household income, by location within and outside piped network — basic and adjusted hedonic pricing model compared

\begin{tabular}{llllll}
\hline & \multicolumn{2}{l}{ Basic hedonic pricing model } & & \multicolumn{2}{l}{ Adjusted hedonic pricing model } \\
& Mean & Median & & Mean & Median \\
\hline Inside piped network & $6.7 \%$ & $7.0 \%$ & $5.1 \%$ & $5.9 \%$ \\
Outside piped network & $6.2 \%$ & $7.0 \%$ & $4.6 \%$ & $5.0 \%$ \\
\hline
\end{tabular}

the piped network. The fact that their willingness to pay is not zero shows that even households located outside of the piped network value connection.

\section{Conclusions and directions for future research}

The main empirical finding of this paper is that the willingness-to-pay for a piped water connection is on average about 5-7 percent of monthly household expenditure. This estimate is at the lower end of the range found in the literature. One likely explanation for this downward deviation is the availability of alternative water sources of good quality, which are good substitutes for piped water (Nauges et al. 2009). Many households in Southwest Sri Lanka have access to private wells that provide high quality water. The result obtained in this paper is in line with the outcome of a contingent valuation analysis for the same sample. The basic hedonic pricing model results in a relatively high willingness to pay for piped water services. This tendency of hedonic pricing models to provide an upper bound of willingness to pay has been noted earlier by many different authors (Vaughan and Ardila 1993; Carson et al. 1996).

Following the methodology of Hutton et al. (2007), average household investment cost in this part of Sri Lanka in 2003-04 was about LKR 44,000. To obtain the total cost of piped water service, the cost of annual operation and maintenance also needs to be taken into account and added to these investment costs. The (one time) connection fee (to be paid by the consumer) in 2003-04 was about LKR 9,000, while an average household would spend about LKR 1,200 per year on its water bills. Assuming a 10 percent discount rate and a 20 year lifetime of the connection, this would mean an average cost of about LKR 58,400. With an average increase in the house appraisal value after the installation of a piped water connection of about LKR 97,000, a piped water connection is a cost effective investment for many households in Southwest Sri Lanka. Yet, for the poorest 25 percent of the population, the house appraisal valueusing the basic hedonic pricing model that results in a upper bound of willingness to pay-increases only by about LKR 42,000 to 60,000 (depending on the model used), such that the installation of a piped water connection may not be sufficient to cover the cost of a piped water supply investment, and hence subsidies may be required to make this an attractive investment option. ${ }^{10}$

\footnotetext{
${ }^{10} \mathrm{~A}$ household in the lowest quartile sees its average house appraisal value increase only by LKR 60,000 when the basic hedonic model is used, and it drops to less than LKR 42,000 when the adjusted hedonic model is applied.
} 
Subsidies in the water sector are common around the world. However, they are often based on connection to the piped network, as in Southwest Sri Lanka, which benefits richer consumers more than poorer consumers (Komives et al. 2005), as the poor tend to be disproportionally less likely to be connected to the piped network. With the information on the profile of the poor and their willingness to pay derived from an analysis such as the present, authorities will be able to design a subsidy system that is better targeted to the poor.

Households out of reach of the network have lower willingness to pay for piped water services than those within reach. Nevertheless, bringing households into the piped network's reach provides benefits to households, whether or not they connect. This suggests that investing in basic infrastructure will generate benefits, as it will increase the overall value of the neighborhoods in which the investments are made. The results presented above show that installing a piped water system in the study area would be viable, because the benefits outweigh the cost of the service.

In view of the many unobserved characteristics that we found, which may explain the tendency of hedonic pricing models to provide an upper bound of willingness to pay, a direction for future research is using the approach proposed by Bajari and Benkard (2005) in the housing market in both developing and developed countries.

Open Access This article is distributed under the terms of the Creative Commons Attribution License which permits any use, distribution, and reproduction in any medium, provided the original author(s) and the source are credited.

\section{References}

Anselin, L., Lozana-Garcia, N., Deichmann, U., Lall, S.: Value of access to water: a spatial hedonic approach applied to Indian cities. World Bank Policy Research Working Paper No. 4533, Washington, DC (2008)

Bajari, P., Benkard, C.L.: Demand estimation with heterogeneous consumers and unobserved product characteristics: a hedonic approach. J. Polit. Econ. 113(6), 1239-1276 (2005)

Box, G.E.P., Cox, D.R.: An analysis of transformations. J. R. Stat. Soc. B 26, 211-246 (1964)

Carson, R.T., Flores, N.E., Martin, K.M., Wright, J.L.: Contingent valuation and revealed preference methodolines: comparing the estimates for quasi-public good. Land Econ. 72(1), 80-99 (1996)

De Oca, G.S.M., Bateman, I.J., Tinch, R., Moffatt, P.G.: Assessing the willingness to pay for maintained and improved water supplies in Mexico City. CSERGE Working Paper ECM 03-11 (2003)

Daniere, A.: Estimating willingness to pay for housing attributes: an application to Cairo and Manila. Reg. Sci. Urban Econ. 24, 577-599 (1994)

Ekeland, I., Heckman, J.J., Nesheim, L.: Identification and estimation of hedonic models. J. Polit. Econ. 112(1), 60-109 (2004)

Freeman, A.M.: Hedonic prices, property values and measuring environmental benefits: a survey of the issues. Scand. J. Econ. 81(2), 154-173 (1993)

Goodman, J.L., Ittner, J.B.: The accuracy of home owners' estimates of house value. J. Hous. Econ. 2, 339-357 (1992)

Harapap, B.N., Hartono, D.: Analysis of willingness to pay and determinant of drinking water and sanitation availability in Indonesia using hedonic price model approach and lnistic model. Working Paper in Economics and Development Studies, Department of Economics, Padjadjaran University (2007)

Hutton, G., Haller, L., Bartram, J.: Global cost-benefit analysis of water supply and sanitation interventions. J. Water Health 5(4), 481-501 (2007)

Kain, J.F., Quigley, J.M.: Housing market discrimination, home-ownership, and savings behavior. Am. Econ. Rev. 62(3), 263-277 (1972)

Keskin, B.: Hedonic analysis of price in the Istanbul housing market. Int. J. Strateg. Prop. Manag. 12, 125-138 (2008) 
Komives, K., Foster, V., Halpern, J., Wodon, Q., Abdullah, R.: Water, electricity and the poor: who benefits from utility subsidies? The World Bank, Washington, DC (2005)

Nauges, C., van den Berg, C.: Demand for piped and non-piped water supply services: evidence from Southwest Sri Lanka. Environ. Resour. Econ. 42, 535-549 (2009)

Nauges, C., Strand, J., Walker, I.: The value of water connections in Central American cities: a revealed preference study. Environ. Dev. Econ. 14(3), 349-370 (2009)

North, J.H., Griffin, C.C.: Water source as a housing characteristic: hedonic property valuation and willingness to pay for water. Water Resour. Res. 29(7), 1923-1929 (1993)

Pattanayak, S.K., Yang, J.-C., Agarwal, C., Gunatilake, H.M., Bandara, H., Ranasinghe, T.: Water, sanitation and poverty in Southwest Sri Lanka. RTI Project number 8812.000 (2004)

Pattanayak, S.K., van den Berg, C., Yang, J.-C., Van Houtven, G.: The use of willingness to pay experiments: estimating demand for piped water connections in Sri Lanka. World Bank Policy Research Working Paper No. 3818, Washington, DC (2006)

Rosen, S.: Hedonic prices and implicit markets: product differentiation in perfect competition. J. Polit. Econ. 82, 34-55 (1974)

Suparman, Y., Folmer, H., Oud, H., Resosudamo, B.P.: Eliciting the willingness to pay for piped water from self-reported rent appraisals in Indonesia: a SEM autoregressive panel approach. Mimeo (2009)

Van den Berg, C., Pattanayak, S., Yang, J.-C., Gunatilake, H.: Getting the assumptions right: private sector participation transaction design and the poor in Southwest Sri Lanka. World Bank Water Supply and Sanitation Sector Board Discussion Paper Series, Paper No. 7 (2006)

Vaughan, W.J., Ardila, S.: Economic analysis of the environmental aspects of investment projects. Working Paper ENP100, Inter-American Development Bank, Washington, DC (1993)

Whittington, D., Mu, X., Roche, R.: Calculating the value of time spent collecting water: some estimates from Ukunda, Kenya. World Dev. 18, 269-280 (1990)

Whittington, D., Pattanayak, S.K., Yang, J.C., Bal Kumar, K.C.: Household demand for improved piped water services: evidence from Kathmandu, Nepal. Water Policy 4, 531-556 (2002)

WHO-UNICEF Joint Monitoring Programme for Water Supply and Sanitation: Progress on Sanitation and Drinking Water: Update, Geneva (2010)

Yusuf, A.A., Koundouri, P.: Willingness to pay for water and location bias in hedonic price analysis: evidence from the Indonesian housing market. Environ. Dev. Econ. 10(6), 821-836 (2005) 